Alpoğuz, D. ve Şahin, A. (2014). Demokratik veya Otoriter Olarak Algılanan Ana-Baba Tutumlarının ilköğretim Öğrencilerinin Türkçe Dersi Akademik Başarılarına Etkisi. Ana Dili Eğitimi Dergisi, 2(3), 53-67.

Ana Dili Eğitimi Dergisi
Journal of Mother Tongue Education
ADED - JOMTE
www.anadiliegitimi.com

\title{
Demokratik veya Otoriter Olarak Algılanan Ana-Baba Tutumlarının ilköğretim Öğrencilerinin Türkçe Dersi Akademik Başarılarına Etkisi ${ }^{*}$
}

Dursune ALPOĞUZ ${ }^{* *}$

Ayfer ŞAHIN ${ }^{* * *}$

Özet

\begin{abstract}
Bu çalışmanın amacı algılanan ana-baba tutumlarının ilköğretim öğrencilerinin Türkçe dersi akademik başarılarına etkilerini araştırmaktır. Araştırmanın örneklemini 2011-2012 Öğretim yılında İstanbul ilinde ikisi devlet, biri özel olmak üzere üç ilköğretim okulunun 2, 3, 4 ve 5. sınıflarında öğrenim gören 569 öğrenci oluşturmaktadır. Veri toplama aracı olarak; öğrencilerin ana-baba tutumlarını belirlemek için "Ana-Baba Tutum Ölçeği”, Türkçe Dersi akademik başarılarını belirlemek için öğrencilere ait not çizelgeleri kullanılmıştır. Verilerin analizinde, yüzde, aritmetik ortalama, t-testi, tek yönlü varyans analizi (ANOVA) ve Scheffe testi kullanılmıştır. Araştırma sonucunda, anne ve babasını demokratik olarak algılayan öğrencilerin, otoriter olarak algılayan öğrencilere göre akademik başarılarının daha yüksek olduğu tespit edilmiştir. Cinsiyet faktörü ile algılanan baba tutumları arasında anlamlı farklııklar bulunurken, algılanan anne tutumları ve Türkçe dersi akademik başarıları arasında farklılık olmadığı tespit edilmiştir. Ayrıca araştırmaya katılan öğrencilerin sınıf seviyeleri ile algıladıkları anababa tutumları ve Türkçe dersi akademik başarıları arasında anlamlı farklılıklar olduğu saptanmıştır.
\end{abstract}

Anahtar kelimeler: Tutum, demokratik ana-baba tutumu, otoriter ana-baba tutumu, akademik başarı

\section{The Effect of Democratic or Authoritarian Perceived Parent Attitudes on Primary School}

\section{Students' Academic Success at Turkish Language}

\begin{abstract}
The aim of this research is to investigate the effect of perceived parent attitudes on primary school students' academic success at Turkish Language Course. The sample of the research is composed of 569 students who are studying at the $2 \mathrm{nd}, 3 \mathrm{rd}$, 4th and 5th grades of 2 state and 1 private primary schools in İstanbul in 2011-2012 Academic Year. As data collection tool, in order to define parent attitudes "Parent attitude Scale" is used and to define academic success at Turkish Language Course , the transcripts of the students are used. For data analysis, percentage, arithmetic mean, $\mathrm{t}$-test, one way analysis of variance (ANOVA) and Scheffe test are applied. As a result of the research it is defined that the students who perceive their parents as democratic are more successful than those who perceive their parents as authoritarian. While there is meaningful difference between gender and perceived father attitudes, there is not a meaningful difference between perceived mother attitudes and academic success at Turkish Language Course. Moreover, it was defined that there is meaningful difference between the class level of the students and perceived parent attitudes and academic success at Turkish Language Course.
\end{abstract}

Key words : attitude, democratic parent attitude, authoritarian parent attitude, academic success

\footnotetext{
* Bu makale, birinci yazarın ikinci yazar danışmanlığında hazırladığı yüksek lisans tezinden üretilmiş ve On Üçüncü Ulusal Sınıf Öğretmenliği Sempozyumunda sözlü bildiri olarak sunulmuştur.

${ }^{* *}$ Hasan Tahsin İlkokulu Sınıf Öğretmeni, İstanbul. E-posta: dursune umucu@windowslive.com

${ }^{* * *}$ Yrd. Doç. Dr., Ahi Evran Üniversitesi Illköğretim Bölümü, Sınıf Öğretmenliği Anabilim Dalı, Kırşehir.

E-posta: ayfersahin1@gmail.com
} 


\section{Giriş}

Ana-baba tutumları çocukların kişiliklerinin oluşumunda oldukça etkilidir. Ebeveynler çocuklarına model oluşturacağından, çocuk özdeşim modellerinden edindikleri benzer tutumları sergilerler. Ana-babanın çocuğuna yönelttiği tutumların doğruluğu büyük ölçüde onların mutlu, kendine güvenen, bağımsız kişilikli bireyler olarak yetişmesine vesile olur (Yavuzer, 2011).

Kişiliği gelişim açısından inceleyen kuramcıların çoğu kişiliğin biçimlenmesini çocukluğun ilk yıllarına dayandırmaktadır: Psikanalitik yaklaşımın oluşturucusu Freud "Kişilik Gelişimi Kuramı" nda; yetişkin kişiliklerimizin yaşamımızın ilk beş ya da altı yılındaki deneyimlerimizle oluştuğunu savunmaktadır. Freud gibi Adler de yaşamımızın ilk birkaç yılının yetişkin kişiliğinin oluşumunda son derece önemli olduğuna inanmış ve bu süreçte ana-babanın etkisine değinmiştir. Horney kuramında çocuklukta yaşanan kişiler arasındaki bozuk ilişkilere değinmiş, özellikle kaygı duygusunu güçlendiren aile ortamlarında büyüyen çocuklar üzerine araştırmalar yapmıştır. Ana-babanın yaptı̆̆ı tutarsızlıkların, egemenlik sağlamanın, küçümseyici tutumların, sevgi ve saygı eksikliğinin, aşırı korumacılığın, ayrımcılığın ve aralarındaki tartışmada çocukların taraf tutmalarını istemelerinin çocuklarda istenmeyen davranışlara yol açtığını belirtmiştir. Ayrıca bu kaygılardan kurtulmak için; bazı çocukların çaresizliklerini vurgulayarak kabul görmek istediklerini, bazılarının da, saldırganlığı ve düşmanlığı kötü aile ortamıyla başa çıkmanın en iyi yolu olarak gördüklerini ifade etmiştir. Bazı çocukların ise kaygıdan arınmak için insanlara bağımlı ya da düşmanca davranmak yerine hiç kimseyle ilişki kurmadığını belirtmiştir (Burger, 2006). Diğer bir kuramcı Erikson 'un gelişim evresinde, yaşamın ilk yılında ihtiyaçlarının doyurulması, güven duygusunu geliştirmesi çocuğun annesiyle olan ilişkisine bağıdır. Güven duygusu annenin çocuğunu sevmesi, okşaması, ilgilenmesi sonucu oluşmaktadır. Güveni hisseden çocuğun aynı zamanda iyimserlik ve mutluluk temelleri gelişir (Özyurt ve Girgin, 2000). Kişilik kuramını benlik üzerine inşa eden Rogers, insanların yerine getirecekleri işlevleri daha bütünlüklü olarak gerçekleştirmelerinde, olumlu bir bakışla büyütülmelerinin etkisi olduğunu belirtmiştir. Rogers ana-baba için en iyi yaklaşımın; çocuğun duygularını geçerli kabul etmek ve yanlış olan duygu, düşünce ve davranışlarının neden benimsenmemesinin nedenlerinin açıklaması gerektiğini ifade etmiştir (Atkinson vd. 2002).

Ailenin mimarı olan ana-babaların kişilikleri, tutum ve davranışları ailenin tümünü etkilemektedir. Özellikle çocukların disipline edilmesinde ana-babaların çocuk yetiştirmedeki farklı yaklaşımları çocuklarda bazen olumlu bazen olumsuz etkiler bırakmaktadır. Farklı ana baba tutumlarını altı başıkta toplamak mümkündür. Bunlar; baskıcı ve otoriter tutum, gevşek tutum, dengesiz ve kararsız tutum, koruyucu tutum, ilgisiz ve kayıtsız tutum, güven verici, demokratik tutum. Ana-baba tutumları gelişmekte olan çocuğa model olacağından çocuğun kişiliğini etkilemektedir. 
Demokratik veya Otoriter Olarak Algılanan Ana-Baba Tutumlarının İlköğretim Öğrencilerinin Türkçe Dersi Akademik Başarılarına Etkisi

Geçmişten günümüze "Çocukları daha iyi nasıl yetiştiririz?" konusu araştırılmıştır. Toplumbilimciler 16. yüzyılda özellikle Avrupa' da yayınlanan eserlerde ana-babaların çocuk yetiştirme biçimlerinde farklılıklar olduğunu tespit etmişlerdir. Aileler başlarda çok izin verici tutum sergilerken, 17. yüzyıl ortalarına kadar bu tutumdan vazgeçmeye ve çocuklarını daha fazla sınırlamaya başlamışlardır. Fakat 18. yüzyılda özellikle İngiliz burjuva ailelerde tekrar izin verici tutuma dönüş başlamış olmasına rağmen; 19. yüzyılda ailelerin büyük çoğunluğu çocuklarını istenmeyen davranışlarından dolayı tuvaletlere, bodrumlara kapatmış, sert disiplin yoluna gitmişlerdir. 19. yüzyıl ikinci yarısından itibaren Amerikalı ve Avrupalı eğitmenler çocuklara özgürlük tanımaları konusunda uyarılarda bulunmuşlardır. 20. yüzyılı etkisi altında bırakan isimlerden biri olan Locke (2004) ise özellikle ısrarları ve üstelemeleri ile her şeye sahip olduklarını düşünen çocukların baskı altına alınması gerektiğini belirtmiştir. Bunu çocukların sağduyuları ile ilişkilendiren yazar çocukların sağduyuları ne kadar az ise o kadar çok bağlı bulundukları kişilerin gücü, baskısı ve yönlendirmesi altında olmaları gerektiğini öne sürmüştür. Kısacası ailenin tutumu konusu zaman zaman ileri, zaman zaman daha tutucu görüşlerden etkilenmeye devam ederek zamanımızda da arayışlarını sürdürmektedir (Ekşi, 1990).

Anne baba tutumlarının çocukların akademik başarıları üzerine olan etkileri de (Çelenk, 2003; Nimsi, 2006; Kaya, Bozaslan ve Genç; 2012) yapılan araştırmalar arasındadır. Başarı, “önceden belirlenmiş hedefler doğrultusunda, planlı ve programlı bir şekilde çok çalışarak ve çaba göstererek istenilen sonuca ulaşma işidir" (Elmacıoğlu,1998:117). Başarıyı motivasyon sağlamaktadır ve başarı güdüsünün gelişmesinde toplumsal çevrenin rolü birçok yazar tarafından vurgulanmıştır. Bu güdünün gücü üzerinde kişinin enerji düzeyi, okul eğitimi ve aile desteği gibi kültürel etkiler ile bireyde bağımsızlığı, kendine güveni geliştirecek çocuk eğitimi etkilidir (Kasatura, 1991). Ayrıca, zekâ, verimli ve düzenli ders çalışma, sorumluluk, ilgi ve yetenekler, beden ve ruh sağlığı, aile ile ilgili sıkıntılar, arkadaş çevresi ile ilgili sıkıntılar, öğretim yaşantısı ile ilgili sıkıntılar, öğretmen desteği, arkadaş desteği, aile desteği ve sınav kaygısı gibi etmenler akademik başarıyı etkileyen diğer bazı faktörlerdir (Yıldırım, 2010).

Akademik başarı ile zekâ arasındaki pozitif ilişkinin kabul görmesinin yanı sıra, akademik başarıyı etkileyen zihinsel olmayan çevre, aile, okul, sosyoekonomik durum gibi birçok faktörle ilişkili olduğu öne sürülmektedir. Yapılan araştırmalar akademik başarı ile duygusal zekâ (Adıgüzel, 2011; Kavcar, 2011); sosyoekonomik değişkenler ve okulun eğitim kaynakları (Ünal, 2001; Savaşçı, 2010;); devamsızlık sorunu (Altınkurt, 2008); farklı öğrenme yaklaşım ve yöntemleri (Yücel, 2011; Arısoy, 2011; Toksoy, 2009; Aydede, 2006; Kaşarcı, 2013; Moralar, 2012); gündelik sıkıntılar (Yıldırım, 2006) arasında manidar ilişki olduğunu göstermektedir. Ailenin eğitim hataları, benimsedikleri tutum ve davranışlardaki kararsızlık, eğitime bakış açısındaki farklılıklar başarıyı olumsuz yönde etkilemektedir. 
Bunların yanı sıra ev ortamındaki huzursuzluk, çocuğun tanımadan yetiştirilmesi de başarısızlığa yol açan durumlardandır (Razon, 1987). Ebeveyn tutumlarının başarı üzerine etkisini araştırmak amaçlı yapılan çalışmalarda da genellikle demokratik tutuma sahip ana-baba çocuklarının akademik başarılarının daha yüksek olduğu sonucuna ulaşılmıştır (Gökçedağ, 2001; Yılmazer, 2007; Kaya, Bozaslan, Genç; 2012).

Bu çalışmanın amacı algılanan ana-baba tutumlarının ilköğretim öğrencilerinin Türkçe dersi akademik başarılarına olan etkilerini araştırmaktır. Araştırmanın; ilköğretim okullarında öğrenim gören 2, 3, 4 ve 5. sınıf öğrencilerinin algıladıkları ana-baba tutumlarının, Türkçe dersinde nasıl bir başarı sağladığını ortaya koymak suretiyle, anne babaların ve eğitimcilerin çocuklara karşı olan davranışlarında stratejiler geliştirmelerinde katkı sağlayacağına inanılmaktadır.

Bu amaç doğrultusunda; "Demokratik veya otoriter olarak algılanan ana-baba tutumlarının ilköğretim öğrencilerinin Türkçe dersi akademik başarılarına etkisi nedir?" sorusu bu araştırmanın problem cümlesini oluşturmaktadır. Ayrıca araştırmada şu alt problemlere cevap aranmıştır:

1. İlköğretim öğrencilerinin algıladıkları ana-baba tutumları nasıldır?

2. Öğrencilerin algıladıkları ana-baba tutumları cinsiyet özelliklerine göre farklılık göstermekte midir?

3. İlköğretim öğrencilerinin algıladıkları ana-baba tutumları sınıf seviyesine göre farklılık göstermekte midir?

4. İlköğretim öğrencilerinin Türkçe dersi akademik başarı düzeyleri cinsiyete göre anlamlı bir farklılık göstermekte midir?

5. İlköğretim öğrencilerinin Türkçe dersi akademik başarı düzeyleri sınıf seviyesine göre farklılık göstermekte midir?

6. Algılanan ana-baba tutumlarına göre öğrencilerin Türkçe dersi akademik başarıları farklılık göstermekte midir?

\section{Yöntem}

Bu araştırmada ilişkisel tarama modeli kullanılmıştır. Araştırmada ilköğretim öğrencilerinin başarı durumları cinsiyet, sınıf seviyesi ve öğrencilerin algıladıkları ana-baba tutumları açısından incelenmiştir. Araştırma nicel bir araştırmadır.

\section{Evren ve Örneklem}

Araştırmanın evrenini, İstanbul ili sınırları içerisinde 2011-2012 Eğitim-Öğretim yılında 2, 3, 4, ve 5. sınıfa devam eden 843.629 öğrenci oluşturmaktadır. Çalışmanın örneklemini ise 2011-2012 öğretim yılında İstanbul ili Arnavutköy, Topkapı ve Bakırköy ilçelerinden ulaşılabilen ve evrenin özelliklerini yansıtan üç ilköğretim okulunun 2.3.4 ve 5. sınıflarında öğrenim gören 569 öğrenci 
Demokratik veya Otoriter Olarak Algılanan Ana-Baba Tutumlarının İlköğretim Öğrencilerinin Türkçe Dersi Akademik Başarılarına Etkisi

oluşturmuştur. Devlet okullarında öğrenim gören 421 öğrencinin $218^{\prime} i$ kız, 210'u erkek öğrenciden oluşurken; özel okulda öğrenim gören 141 öğrencinin 57'si kız, 84'ü erkek öğrenciden oluşmaktadır.

\section{Veri Toplama Araçları}

Araştırmada Anne-baba tutumlarını belirlemek için Polat (1986) tarafından geliştirilen ölçek kullanılmıştır. Ölçek, anne-babaların otoriter ve demokratik tutumlarını ölçmektedir. Anne puanı ve baba puanı olmak üzere iki ayrı puan verilerek kullanılan Ana-Baba Tutum Ölçeği, öğrencilerin anne ve babalarının kendilerine yönelik tutumlarını değerlendirmek üzere 12 maddelik demokratik, 14 maddelik otoriter boyut olmak üzere toplam 26 maddeden oluşmaktadır Ölçekte kritik değer olarak; anneler için 8, babalar için 9 puanı belirlenmiştir. Yani annelerin 8, babaların 9 puan üzerinde almaları onların otoriter tutum sergilediğini, 8/9 puan altında almaları ise demokratik tutum sergilediklerini göstermektedir. Ölçek 2, 3, 4 ve 5. sınıf olmak üzere her sınıftan ikişer sınıf öğretmeni tarafından incelenmiştir. Ahi Evran Üniversitesinden iki uzmanın görüşü alınıp son hali verilen ölçeğin; İstanbul'da asıl örneklem grubunda yer almayan 100 öğrenci ile pilot uygulaması yapılmış ve baba tutumu alt ölçeği için KR 20 güvenirlik katsayısı 0.70; anne tutumu alt ölçeği için KR 20 güvenirlik katsayısı 0.68 olarak tespit edilmiştir. Türkçe Dersi akademik başarılarını belirlemek için I. dönem not çizelgeleri kullanılmıştır.

\section{Verilerin Analizi}

Araştırma için geliştirilen anketler uygulanıp toplandıktan sonra veriler bilgisayar ortamına aktarılmıştır. Verilerin istatistiksel analizinde SPSS 15 paket programından yararlanılmıştır. Elde edilen verileri betimlemek için ise yüzde (\%), aritmetik ortalama $(\bar{X})$, standart sapma (Ss), t Testi analizi, tek yönlü varyans analizi (ANOVA) kullanılmıştır.

\section{Bulgular}

Bu başlık altında ilköğretim 2, 3, 4 ve 5. sınıf öğrencilerinin algıladıkları ana-baba tutumları ve Türkçe dersi akademik başarılarına olan etkisine ilişkin bulgular verilmiştir.

\section{Illköğretim Öğrencilerinin Algıladıkları Ana-Baba Tutum Düzeyleri}

Illköğretim öğrencilerinin demokratik ve otoriter olarak algıladıkları anne ve baba tutumlarına ilişkin betimsel veriler Tablo 1'de gösterilmiştir.

Tablo 1. Ilköğretim Öğrencilerinin Algıladıkları Ana-Baba Tutumu Betimsel Verileri

\begin{tabular}{lcccl}
\hline Baba Tutumu & $\mathbf{N}$ & $\overline{\mathbf{X}}$ & $\mathbf{\%}$ & Ss \\
\hline Demokratik Algılayanlar & 336 & 5,36 & 59 & 1,689 \\
Otoriter Algılayanlar & 233 & 12,63 & 41 & 3,026 \\
Anne Tutumu & $\mathbf{N}$ & $\overline{\mathbf{X}}$ & $\%$ & Ss \\
Demokratik Algılayanlar & 276 & 5,03 & 51 & 1,531 \\
Otoriter Algılayanlar & 293 & 11,81 & 49 & 3,091 \\
\hline
\end{tabular}


Tablo 1'de görüldüğg̈ü üzere araştırmaya katılan öğrencilerin 336'sı babasını demokratik, 233'ü babasını otoriter olarak algılamaktadır. Ayrıca 276 öğrencinin annesini demokratik olarak, 293 öğrencinin de otoriter olarak algıladığı belirlenmiştir. Öğrencilerin \% 59'u babalarını demokratik, \% 41'i otoriter olarak algılamaktadır. Öğrencilerin \% 51' i annelerini otoriter, \% 49'u demokratik olarak algılamakta olduğu tespit edilmiştir. Bu bulgular öğrencilerin annelerini daha otoriter babalarını da daha demokratik olarak algıladıklarını göstermektedir. Bu bulgular öğrencilerin annelerini daha fazla demokratik tutuma, babalarını ise daha çok otoriter tutuma sahip olarak algıladıklarını göstermektedir.

\section{İlköğretim Öğrencilerin Algıladıkları Ana-Baba Tutum Ölçeği Ortalama Puanlarının Cinsiyet Özelliklerine Göre Karşılaştırılması}

Ana-baba tutum ölçeği ortalama puanlarının cinsiyet özelliklerine göre karşılaştııılmasına ilişkin ttesti sonuçları Tablo 2 ve Tablo 3'te verilmiştir.

Tablo 2. Illköğretim Öğrencilerinin Algıladıkları Baba Tutumu Puan Ortalamalarının Cinsiyet Özelliklerine Göre Farklılığını Gösteren t - Testi Tablosu

\begin{tabular}{lcccccc}
\hline CINSIYET & $\mathbf{N}$ & $\overline{\mathrm{X}}$ & $\mathbf{S}$ & $\mathbf{t}$ & $\mathbf{s d}$ & $\mathbf{p}$ \\
\hline KIz & 275 & 7,89 & 4,1065 & & & \\
Erkek & 294 & 8,76 & 4,3861 & $-2,451$ & 567 &, 015 \\
\hline
\end{tabular}

${ }^{*}$ Kritik değer; Anneler için $\bar{X}=8.00$, Babalar için $\bar{X}=9.00$

Tablo 2'de görüldüğü üzere kız öğrenciler ile erkek öğrencilerin algılanan baba tutumları arasında anlamlı bir farklılık tespit edilmiştir $\left[\mathrm{t}_{(567)}=-2,451 ; \mathrm{p}<05\right]$. Bu farklılık kız öğrenciler lehinedir. Kız öğrencilerin algılanan baba tutum ortalamaları $(\bar{X}=7,89)$ iken erkek öğrencilerin algılanan baba tutum ortalamaları $(\overline{\mathrm{X}}=8,76)^{\prime}$ dir. Bu bulgular, kız öğrencilerin babalarını daha demokratik, erkek öğrencilerin ise daha otoriter olarak algıladıklarını göstermektedir.

Tablo 3. İlköğretim Öğrencilerinin Algıladıkları Anne Tutumu Puan Ortalamalarının Cinsiyet Özelliklerine Göre Farklılığını Gösteren t - Testi Tablosu

\begin{tabular}{|c|c|c|c|c|c|c|}
\hline CINSIYET & $\mathbf{N}$ & $\bar{X}$ & S & $\mathbf{t}$ & sd & $\mathbf{p}$ \\
\hline $\mathrm{K} / \mathrm{Z}$ & 275 & 8,18 & 4,2430 & \multirow{2}{*}{$-1,905$} & \multirow{2}{*}{567} & \multirow{2}{*}{,057 } \\
\hline Erkek & 294 & 8,85 & 4,1249 & & & \\
\hline
\end{tabular}

Cinsiyet özelliklerine göre algılanan anne tutumları incelendiğinde kız öğrencilerin ortalama puanları $(\bar{X}=8,18)$ iken erkek öğrencilerin ortalama puanlarının $(\bar{X}=8,85)$ olduğu tespit edilmiştir. Bu sonuçlara göre kız ve erkek öğrenciler arasında anne tutumları ile ilgili olarak algılamaları arasında istatistiksel olarak anlamlı bir farklılık bulunmamıştır. $\left[t_{(567)}=-1,905 ; p>05\right]$. 
Demokratik veya Otoriter Olarak Algılanan Ana-Baba Tutumlarının İlköğretim Öğrencilerinin Türkçe Dersi Akademik Başarılarına Etkisi

\section{İlköğretim Öğrencilerin Algıladıkları Ana-Baba Tutum Ölçeği Ortalama Puanlarının Sınıf Seviyesine Göre Karşılaştırılması}

Algılanan baba tutumları ortalama puanlarının sınıf seviyesine göre karşılaştırılmasına ilişkin betimsel veriler Tablo 4'te, varyans analizi sonuçları Tablo 5' te verilmiştir.

Tablo 4. Ilköğretim Öğrencilerinin Sınıf Seviyesine Göre Algılanan Baba Tutumu Puan Ortalamaları Betimsel Verileri

\begin{tabular}{ccccc}
\hline Sınıf Seviyesi & Gruplar & $\mathbf{N}$ & $\overline{\mathbf{X}}^{*}$ & Ss \\
2.sınıf & 1 & 164 & 9,48 & 4,2288 \\
3.sınıf & 2 & 140 & 8,02 & 4,3810 \\
4. sınıf & 3 & 132 & 8,25 & 3,9667 \\
5.sınıf & 4 & 133 & 7,34 & 4,2284 \\
\hline
\end{tabular}

${ }^{*}$ Kritik değer; Anneler için $\bar{X}=8.00$, Babalar için $\bar{X}=9.00$

Tablo 4'te görüldüğü üzere 2. Sınıfa devam eden öğrencilerin algıladığı baba tutumu puan ortalaması $(\bar{X}=9,48)$; 3. Sınıfa devam eden öğrencilerin baba tutumu algılama puan ortalaması $(\bar{X}=8,02) ; 4$. Sınıfa devam eden öğrencilerin baba tutum puan ortalaması $(\bar{X}=8,25)$ ve 5 . Sınıfa devam eden öğrencilerin baba tutumu puan ortalaması ise $(\overline{\mathrm{X}}=7,34)$ olarak bulunmuştur.

Tablo 5. İlköğretim Öğrencilerinin Algıladıkları Baba Tutumlarının Sınıf Seviyelerine Göre Farklılaşıp Farklılaşmadığına İlişkin Tek Yönlü Varyans Analizi (ANOVA) Sonuçları

\begin{tabular}{|c|c|c|c|c|c|c|}
\hline $\begin{array}{l}\text { Varyansın } \\
\text { Kaynağı }\end{array}$ & KT & Sd & KO & $\mathbf{F}$ & $\mathbf{p}$ & $\begin{array}{c}\text { Fark } \\
\text { (Scheffe) }\end{array}$ \\
\hline Gruplar arası & 361,978 & 3 & 120,659 & \multirow{3}{*}{6,814} & \multirow{3}{*}{,000 } & \multirow{3}{*}{$\begin{array}{l}1-2 \\
3-4\end{array}$} \\
\hline Gruplar içi & 10004,194 & 565 & 17,707 & & & \\
\hline Toplam & 10366,172 & 568 & & & & \\
\hline
\end{tabular}

Algılanan baba tutumları açısından sınıf seviyeleri arasında anlamlı farklılık tespit edilmiştir. $\left[\mathrm{F}_{(3-}\right.$ $\left.{ }_{565}=6,814 p<05\right]$. Baba tutumlarından alınan puanlar açısından bu farklılığın; 2. sınıf öğrencilerinin puan ortalamaları $(\bar{X}=9.48)$ ile 3. sınıf $(\bar{X}=8.02)$ ve 5. sınıf $(\bar{X}=7.34)$ öğrencileri puan ortalamalarından kaynaklandığı görülmüştür. Bu veriler araştırmaya katılan 2. sınıf öğrencilerinin babalarını daha otoriter olarak algıladıklarını, 5. sınıf öğrencilerinin ise babalarını daha demokratik olarak algıladıklarını göstermektedir.

Algılanan anne tutumları ortalama puanlarının sınıf seviyesine göre karşılaştırılmasına ilişkin betimsel veriler Tablo 6'da, varyans analizi sonuçları Tablo 7'de verilmiştir.

Tablo 6. İlköğretim Öğrencilerinin Sınıf Seviyesine Göre Algılanan Anne Tutumu Puan Ortalamaları Betimsel Verileri

\begin{tabular}{cclcr}
\hline Sinıf Seviyesi & Gruplar & $\mathbf{N}$ & $\overline{\mathbf{X}}^{*}$ & Ss \\
2.sınıf & 1 & 164 & 9,51 & 4,0297 \\
3.sınıf & 2 & 140 & 8,26 & 4,3458 \\
4. sınıf & 3 & 132 & 8,68 & 4,1372 \\
5.sınıf & 4 & 133 & 7,42 & 4,0213 \\
\hline
\end{tabular}

*Kritik değer; Anneler için $\bar{X}=8.00$, Babalar için $\bar{X}=9.00$ 
Tablo 6'da görüldüğü üzere 2. sınıfa devam eden öğrencilerin algıladığı anne tutumu puan ortalaması $(\bar{X}=9,51)$; 3. sınıfa devam eden öğrencilerin anne tutumu algılama puan ortalaması $(\bar{X}=8,26) ; 4$. sınıfa devam eden öğrencilerin anne tutum puan ortalaması $(\bar{X}=8,68)$ ve 5 . sınıfa devam eden öğrencilerin anne tutumu puan ortalaması ise $(\overline{\mathrm{X}}=7,42)$ olarak bulunmuştur.

Tablo 7. İlköğretim Öğrencilerinin Algıladıkları Anne Tutumlarının Sınıf Seviyelerine Göre Farklılaşıp Farklılaşmadığına İlişkin Tek Yönlü Varyans Analizi (ANOVA) Sonuçları

\begin{tabular}{llccccc}
\hline $\begin{array}{l}\text { Varyansın } \\
\text { Kaynağı }\end{array}$ & KT & Sd & KO & F & p & $\begin{array}{c}\text { Fark } \\
\text { (Scheffe) }\end{array}$ \\
\cline { 1 - 3 } Gruplar arası & 332,794 & 3 & 110,931 & & & \\
\cline { 1 - 4 } Gruplar içi & 9649,034 & 565 & 17,078 & & \multirow{2}{*}{000} & $1-2$ \\
\cline { 1 - 4 } Toplam & 9981,828 & 568 & & & & $1-4$ \\
\hline
\end{tabular}

Algılanan anne tutumları açısından sınıf seviyeleri arasında fark tespit edilmiştir. $\left[F_{(3-565)}=\right.$ $6,496 p<05]$. Anne tutumlarından alınan puanlar açısından bu farklılığın; 2. sınıf öğrencilerinin puan ortalamaları $(\overline{\mathrm{X}}=9.51)$ ile 3. sınıf $(\overline{\mathrm{X}}=8.26)$ ve 5. sınıf $(\overline{\mathrm{X}}=7.42)$ öğrencileri puan ortalamalarından kaynaklandığı görülmüştür. Bu veriler araştırmaya katılan 2. sınıf öğrencilerinin annelerini daha otoriter olarak algıladıklarını, 5. sınıf öğrencilerinin ise annelerini daha demokratik olarak algıladıklarını göstermektedir.

\section{İlköğretim Öğrencilerinin Türkçe Dersi Akademik Başarı Düzeylerinin Cinsiyete Göre Karşılaştırılması}

Öğrencilerin Türkçe dersi başarı ortalamalarının cinsiyete göre karşılaştırılmasına ilişkin t testi sonuçları Tablo 8'de verilmiştir.

Tablo 8. İlköğretim Öğrencilerinin Türkçe Dersi Akademik Başarı Not Ortalamalarının Cinsiyet Özelliklerine Göre Farklııı̆ını Gösteren t - Testi Tablosu

\begin{tabular}{ccccccc}
\hline CINSIYET & $\mathbf{N}$ & $\bar{X}$ & S & t & sd & p \\
\hline KIz & 275 & 4,19 & 1,1973 & 1,875 & 567 & \multirow{2}{*}{061} \\
Erkek & 294 & 4,00 & 1,2100 & & \\
\hline
\end{tabular}

Türkçe dersi akademik başarı not ortalamalarının öğrencilerin cinsiyet özelliklerine göre farklıı̆ııı gösteren Tablo 8 incelendiğinde $k ı z(\bar{X}=4,19)$ ve erkek $(\bar{X}=4,00)$ öğrenciler bakımından anlamlı bir farklıık bulunmamıştır. [ $t_{(567)}=1,875$ p $\left.>05\right]$. Yani cinsiyet değişkeninin Türkçe dersi akademik başarısı üzerinde olumlu ya da olumsuz bir etkisi olmadığı tespit edilmiştir.

Illköğretim Öğrencilerinin Türkçe Dersi Akademik Başarı Düzeylerinin Sınıf Seviyesine Göre Karşılaştırııması 
Demokratik veya Otoriter Olarak Algılanan Ana-Baba Tutumlarının ilköğretim Öğrencilerinin Türkçe Dersi Akademik Başarılarına Etkisi

Illköğretim öğrencilerinin Türkçe dersi akademik başarı puanlarının sınıf seviyesine göre karşılaştırımasına ilişkin betimsel veriler Tablo 9'da, varyans analizi sonuçları Tablo 10'da verilmiştir.

Tablo 9. İlköğretim Öğrencilerinin Sınıf Seviyesine Göre Türkçe Dersi Başarı Not Ortalamaları Betimsel Verileri

\begin{tabular}{ccccc}
\hline Sınıf Seviyesi & Gruplar & $\mathbf{N}$ & $\overline{\mathbf{X}}^{*}$ & Ss \\
2.sınıf & 1 & 164 & 4,48 &, 94309 \\
3.sınıf & 2 & 140 & 4,30 & 1,07757 \\
4. sınıf & 3 & 132 & 3,40 & 1,45077 \\
5.sınıf & 4 & 133 & 4,08 & 1,06632 \\
\hline
\end{tabular}

Tablo 9'da görüldüğg̈ü üzere 2. sınıfa devam eden öğrencilerin Türkçe dersi akademik başarı not ortalaması $(\overline{\mathrm{X}}=4,48)$; 3. sınıfa devam eden öğrencilerin Türkçe dersi akademik başarı not ortalaması ( $\overline{\mathrm{X}}=4,30) ; 4$. sınıfa devam eden öğrencilerin Türkçe dersi akademik başarı not ortalaması $(\bar{X}=3,40)$ ve 5 . sınıfa devam eden öğrencilerin Türkçe dersi akademik başarı not ortalaması ise $(\overline{\mathrm{X}}=4,08)$ olarak bulunmuştur.

Tablo 10. İlköğretim Öğrencilerinin Türkçe Dersi Akademik Başarı Not Ortalamalarının Sınıf Seviyesine Göre Farklılaşıp Farklılaşmadığına İlişkin Tek Yönlü Varyans Analizi (ANOVA) Sonuçları

\begin{tabular}{|c|c|c|c|c|c|c|}
\hline $\begin{array}{l}\text { Varyansın } \\
\text { Kaynağı }\end{array}$ & KT & Sd & KO & $\mathbf{F}$ & $p$ & $\begin{array}{c}\text { Fark } \\
\text { (Scheffe) }\end{array}$ \\
\hline Gruplar arası & 94,690 & 3 & 31,563 & \multirow{3}{*}{24,356} & \multirow{3}{*}{,000 } & \multirow{3}{*}{$\begin{array}{l}1-3,1-4 \\
2-3,3-4\end{array}$} \\
\hline Gruplar içi & 732,186 & 565 & 1,296 & & & \\
\hline Toplam & 826,875 & 568 & & & & \\
\hline
\end{tabular}

Illköğretim öğrencilerin Türkçe dersi akademik başarı not ortalamalarının sınıf seviyesine göre farklılık gösterdiği Tablo $10^{\prime}$ da tespit edilmiştir $\left[F_{(3-565)}=24,356 p<05\right]$. Bu testin sonucunda 2 . sınıfa devam eden öğrencilerin Türkçe dersi başarı puan ortalamaları $(\bar{X}=4,48)$ ile dördüncü sınıfa devam öğrencilerin Türkçe dersi başarı puan ortalamaları $(\bar{X}=3,40)$ arasında ikinci sınıf öğrencilerinin lehine; ikinci sınıfa devam eden öğrencilerin Türkçe dersi başarı puan ortalamaları $(\bar{X}=4,48)$ ile beşinci sınıfa devam eden öğrencilerin Türkçe dersi başarı puan ortalamaları $(\bar{X}=4,08)$ arasında ikinci Sınıf öğrencilerinin lehine; üçüncü sınıfa devam eden ilköğretim öğrencilerinin Türkçe dersi başarı puan ortalamaları $(\bar{X}=4,30)$ ile dördüncü sınıfa devam öğrencilerin Türkçe dersi başarı puan ortalamaları $(\bar{X}=3,40)$ arasında üçüncü sınıf öğrencilerinin lehine; üçüncü sınıfa devam eden ilköğretim öğrencilerinin Türkçe dersi başarı puan ortalamaları $(\bar{X}=4,30)$ ile beşinci sınıfa devam eden öğrencilerin Türkçe dersi başarı puan ortalamaları $(\bar{X}=4,08)$ arasında üçüncü sınıf öğrencilerinin lehine anlamlı farklıık olduğu tespit edilmiştir. Sonuçlara göre ikinci sınıf öğrencileri Türkçe dersinde diğer sınıflara göre daha başarılıdır. 


\section{Illköğretim Öğrencilerinin Türkçe Dersi Akademik Başarı Düzeylerinin Algıladıkları Ana-Baba} Tutumlarına Göre Karşılaştırılması

Öğrencilerin Türkçe dersi başarı ortalamalarının algılanan baba tutum puan ortalamasına göre karşılaştırılmasına ilişkin t testi sonuçları Tablo 11'de verilmiştir.

Tablo 11. İlköğretim Öğrencilerin Türkçe Dersi Akademik Başarı Not Ortalamalarının Algılanan Baba Tutumuna Göre Farklılığını Gösteren t - Testi Tablosu

\begin{tabular}{ccccccc}
\hline $\begin{array}{c}\text { Algilanan Baba } \\
\text { Tutumu }\end{array}$ & $\mathbf{N}$ & $\overline{\mathrm{X}}$ & $\mathbf{S}$ & $\mathbf{t}$ & $\mathbf{S d}$ & $\mathbf{p}$ \\
\hline Demokratik & 336 & 4,35 &, 9972 & 6,444 & 567 &, 000 \\
Otoriter & 233 & 3,71 & 1,3729 & & \\
\hline
\end{tabular}

Tablo 11 incelendiğinde; algılanan baba tutumu ile Türkçe dersi akademik başarı arasında anlamlı bir farklılık tespit edilmiştir $\left[t_{(567)}=6,444 ; p<05\right]$. Baba tutumlarını demokratik olarak algılayan öğrencilerin Türkçe dersi başarı notu ortalaması ( $\bar{X}=4,35$ ) iken baba tutumlarını otoriter algılayan öğrencilerin Türkçe dersi başarı notu ortalaması ( $\bar{X}=3,71$ ) olarak bulunmuştur. Bu durum demokratik baba tutumunun çocuğun akademik başarısına olumlu yönde etkisi olduğunu göstermektedir.

Öğrencilerin Türkçe dersi başarı ortalamalarının algılanan anne tutum puan ortalamasına göre karşılaştırılmasına ilişkin $t$ testi sonuçları Tablo 12'de verilmiştir:

Tablo 12. Illköğretim Öğrencilerin Türkçe Dersi Akademik Başarı Not Ortalamalarının Algılanan Anne Tutumuna Göre Farklılığını Gösteren t - Testi Tablosu

\begin{tabular}{ccccccc}
\hline $\begin{array}{c}\text { Algilanan Anne } \\
\text { Tutumu }\end{array}$ & $\mathrm{N}$ & $\overline{\mathrm{X}}$ & $\mathrm{S}$ & $\mathrm{t}$ & $\mathrm{Sd}$ & $\mathrm{p}$ \\
\hline $\begin{array}{c}\text { Demokratik } \\
\text { Otoriter }\end{array}$ & 276 & 4,41 &, 9668 & 6,387 & 567 &, 000 \\
\hline
\end{tabular}

Tablo 12 incelendiğinde; algılanan anne tutumu ile Türkçe dersi akademik başarı arasında anlamlı bir farklılık tespit edilmiştir $\left[\mathrm{t}_{(567)}=6,387 ; \mathrm{p}<05\right]$. Anne tutumlarını demokratik olarak algılayan öğrencilerin Türkçe dersi başarı notu ortalaması $(\bar{X}=4,41)$ iken anne tutumlarını otoriter algılayan öğrencilerin Türkçe dersi başarı notu ortalaması $(\bar{X}=3,79)$ olarak bulunmuştur. Bu durum akademik başarıyı etkileme yönüyle otoriter anne tutumu yerine demokratik anne tutumu lehinedir.

\section{Sonuç, Tartışma ve Öneriler}

Algılanan ana-baba tutumlarının yüzdelik değerleri incelendiğinde; öğrencilerin \% 59'u babalarını demokratik, \% 41'i otoriter olarak algılamaktadır. Öğrencilerin \% 51' inin annelerini otoriter, \% 


\section{Demokratik veya Otoriter Olarak Algılanan Ana-Baba Tutumlarının İlköğretim Öğrencilerinin Türkçe Dersi Akademik Başarılarına Etkisi}

49'unun demokratik olarak algılamakta olduğu tespit edilmiştir. Bu bulgular öğrencilerin annelerini daha otoriter babalarını daha demokratik olarak algıladıklarını göstermektedir. Onat (2010) araştırmasında lise birinci sınıf öğrencilerinin yılmazlık düzeylerini ana babalarını demokratik ya da otoriter olarak algılamalarına göre ve bazı demografik değişkenlere göre incelemiştir. Araştırmaya katılan 200 öğrencinin 127'si annesini demokratik olarak algılarken 73' ü otoriter olarak algıladığı; yine öğrencilerin $122^{\prime}$ sinin babalarını demokratik olarak, $78^{\prime}$ inin ise otoriter olarak algıladığı tespit edilmiştir. Şendil ve Demir (2008) yaptıkları araştırma sonucunda ebeveynlerin tutumlarının cinsiyetlerine göre farklılık gösterdiğini, demokratiklik boyutunda annelerin babalardan anlamlı derecede daha yüksek puan aldıklarını tespit etmişlerdir. Kültürümüzde babaların daha çok otoriter davranış özelliklerini benimsemiş olmaları ile açıklanan bu sonuçların araştırmamızın bulgularıyla örtüşmediği görülmektedir.

Ana-baba tutumunu değerlendirme ölçeği ortalama puanları cinsiyet değişkenine göre incelenmiş, demokratik ve otoriter baba tutum puan ortalamaları arasında anlamlı farklılık bulunmuştur. Kız öğrencilerin algılanan baba tutum ortalamaları $(\bar{X}=7,89)$ iken erkek öğrencilerin algılanan baba tutum ortalamaları $(\bar{X}=8,76)$ olduğu, bu farklılı̆ın kız öğrenciler lehine olduğu tespit edilmiştir. Bu bulgular, kız ve erkek öğrencilerin babalarını demokratik olarak algıladığını göstermekle birlikte, erkek öğrencilerin babalarını kız öğrencilere göre biraz daha otoriter tutuma yakın olarak algıladıklarını göstermektedir. Kız ve erkek öğrencilerin algıladığı anne tutumları arasında istatistiksel olarak anlamlı bir farklılık bulunmamıştır. Bu sonuç daha önce yapılan bazı araştırmalarla (Gelir, 2009; Uyanık, 2007) tutarlılık gösterirken bazı araştırmalar bu bulgu ile örtüşmemektedir. Dinçer (2008) farklı ekonomik düzeydeki lise öğrencileri üzerine yaptığı araştırmasında cinsiyet faktörünün anababa tutumları açısından farklııı oluşturduğunu bulmuştur. Nimsi (2006) ilköğretim ikinci sınıf öğrencilerinin ana-baba tutumları, okul başarıları ve sınıf içi etkinliklere katılımlarını konu aldığı araştırmasında, öğrencilerin ana-baba tutumlarının cinsiyete göre farklılık olduğunu bulmuştur.

Ana-baba tutumunu değerlendirme ölçeği ortalama puanlarının öğrencilerin sınıf seviyesine göre değişip değişmediği incelenmesinde, algılanan ana-baba tutumlarının öğrencilerin sınıf seviyelerine göre farklılık gösterdiği tespit edilmiştir. Baba tutumlarından alınan puanlar açısından bu farklılığın; 2. sınıf öğrencilerinin puan ortalamaları $(\bar{X}=9.48)$ ile 3 . sınıf $(\bar{X}=8.02)$ ve $5 . \operatorname{sınıf~}(\bar{X}=7.34)$ öğrencileri puan ortalamalarından kaynaklandığı görülmüştür. Bu veriler araştırmaya katılan 2. sınıf öğrencilerinin babalarını otoriter olarak, 3, 4 ve 5. sınıf öğrencilerinin ise babalarını daha demokratik olarak algıladıklarını göstermektedir. Anne tutumlarından alınan puanlar açısından bu farkıılığın; 2 . sınıf öğrencilerinin puan ortalamaları $(\bar{X}=9.51)$ ile 3. sınıf $(\bar{X}=8.26)$ ve 5 . sınıf $(\bar{X}=7.42)$ öğrencileri puan ortalamalarından kaynaklandığı görülmüştür. Bu veriler araştırmaya katılan 2, 3 ve 4 . sınıf öğrencilerinin annelerini otoriter olarak algılarken, 5. sınıf öğrencilerinin ise demokratik olarak 
algıladıklarını göstermektedir. Bu durum anne ve babalar tarafından oluşturulan kurallara uyma noktasında çocukların onları otoriter olarak algılamalarına neden olmuş olabileceği şeklinde yorumlanmıştır. Başka bir ifadeyle yaşları büyüdükçe çocuklar bu kurallara alışmış veya anne ve babalar da kurallara alışan çocuklarına karşı daha olumlu tutumlarla yaklaşmaya başlamış olabileceği şeklinde değerlendirilmiştir. Nitekim okula yeni başlayan çocukların, sabah kendisini uyandırmaya gelen, planlı çalışma konusunda kendisini disipline etmeye çalışan anne ve babalarını daha otoriter olarak algılamaları mümkündür. Anne ve babalarını daha demokratik olarak algılamaya başlamalarında ise yaşın ilerlemesi, belli bir disiplin anlayışını benimsemiş olmaları gibi nedenler ileri sürülebilir.

Cinsiyet faktörünün Türkçe dersi akademik başarı not ortalamaları üzerine anlamlı bir farklılık oluşturmadığı tespit edilmiştir. Keskin ve Sezgin (2009)'in ergen öğrenciler üzerine yaptıkları çalışma araştırmanın bulgusunu desteklerken; Yıldırım (2006) ve Acıyan (2008) cinsiyet değişkeninin akademik başarının önemli bir yordayıcısı olduğu sonucuna ulaşmışlardır. Arı (2007) ise öğrencilerin okul başarılarını etkileyen çeşitli faktörlerin incelenmesi konulu çalışmasında bu bulguyla örtüşmeyen sonuçlara ulaşmışır. Arı'nın araştırmasında çalışmaya katılan kız ve erkek öğrencilerin matematik dersinde aynı başarıyı gösterdikleri bulunmuşken, Türkçe dersinde kız öğrencilerin erkek öğrencilerden daha fazla başarı gösterdikleri bulunmuştur.

Araştırmada Türkçe dersi başarı puan ortalamaları ile sınıf seviyesi arasında farklıılı̆ın olup olmadığı incelenmiştir. İlköğretim öğrencilerin Türkçe dersi akademik başarı notu ortalamalarının sınıf seviyesine göre farklıık gösterdiği saptanmıştır. Bu farklılı̆ın; 2. sınıfa devam eden öğrencilerin Türkçe dersi başarı puan ortalamaları $(\bar{X}=4,48)$ ile 4 . sınıfa devam öğrencilerin Türkçe dersi başarı puan ortalamaları $(\bar{X}=3,40)$ arasında 2. sınıf öğrencilerinin lehine; 2 . sınıfa devam eden öğrencilerin Türkçe dersi başarı puan ortalamaları $(\bar{X}=4,48)$ ile 5 . sınıfa devam eden öğrencilerin Türkçe dersi başarı puan ortalamaları $(\bar{X}=4,08)$ arasında 2. sınıf öğrencilerinin lehine; 3. sınıfa devam eden ilköğretim öğrencilerinin Türkçe dersi başarı puan ortalamaları $(\bar{X}=4,30)$ ile 4. sınıfa devam öğrencilerin Türkçe dersi başarı puan ortalamaları $(\bar{X}=3,40)$ arasında 3. sınıf öğrencilerinin lehine; 3 . sınıfa devam eden ilköğretim öğrencilerinin Türkçe dersi başarı puan ortalamaları $(\bar{X}=4,30)$ ile 5 . sınıfa devam eden öğrencilerin Türkçe dersi başarı puan ortalamaları $(\bar{X}=4,08)$ arasında 3. sınıf öğrencilerinin lehine olduğu tespit edilmiştir. Sonuçlara göre 2. sınıf öğrencileri Türkçe dersinde diğer sınıflara göre daha başarılıdır. Sınıf seviyesinin artması ile azalan puan ortalamalarının beşinci sınıfla beraber artış gösterdiği tespit edilmiştir. Bu durumu ilerleyen yaşın beraberinde farklı kültürel faaliyet alanlarını getirmesi öğrencilerin başarı durumunu da etkilediği şeklinde yorumlamak mümkündür. Ayrıca dördüncü sınıfta öğrencilerin işledikleri ders sayısının artması ve sarf edilen 


\section{Demokratik veya Otoriter Olarak Algılanan Ana-Baba Tutumlarının İlköğretim Öğrencilerinin Türkçe Dersi Akademik Başarılarına Etkisi}

potansiyel eforun dersler arasında bölünmesi de başarıyı olumsuz yönde etkilemiş olabilir. Nitekim beşinci sınıfta başarının tekrar artış gösteriyor olması dördüncü sınıfta ilk kez karşılaşılan derslere aşina olunmasıyla ilgili olabilir. Keskin ve Sezgin (2009) de bir grup ergenin akademik başarısına etki eden faktörlerin belirlenmesi amacıyla yaptıkları araştırmada, öğrencilerin yaşının ilerlemesiyle akademik başarılarının azaldığı sonucuna ulaşımıştır. Acıyan (2008) tarafından da ortaöğretim öğrencileri ile yapılan çalışmada araştırmaya katılan öğrencilerin ağırlıklı yıl sonu ortalamalarının sınıflara göre benzer bir şekilde farklılaşmakta olduğu saptanmıştır. Araştırmada en yüksek not ortalamasına sahip olan dokuzuncu sınıflarken en düşük not ortalamasının ise onuncu sınıflara ait olduğu bulunmuştur.

Algılanan anne ve baba tutumu ile Türkçe dersi akademik başarı arasında anlamlı bir farklılık tespit edilmiştir. Baba tutumlarını demokratik olarak algılayan öğrencilerin Türkçe dersi başarı notu ortalaması $(\bar{X}=4,35)$ iken baba tutumlarını otoriter algılayan öğrencilerin Türkçe dersi başarı notu ortalaması ( $\overline{\mathrm{X}}=3,71$ ) olarak bulunmuştur. Anne tutumlarını demokratik olarak algılayan öğrencilerin Türkçe dersi başarı notu ortalaması $(\bar{X}=4,41)$ iken anne tutumlarını otoriter algılayan öğrencilerin Türkçe dersi başarı notu ortalaması ( $\bar{X}=3,79$ ) olarak bulunmuştur. Bu durum akademik başarıyı etkileme yönüyle otoriter ana-baba tutumu yerine demokratik anne tutumu lehinedir. Bu sonuçlar demokratik ana-baba tutumunun çocuğun akademik başarısına olumlu yönde etki ettiğini ortaya koymaktadır. Araştırmanın bulguları daha önce yapılan araştırmalardaki (Özben, 1995; Çelenk, 2003; Yıldırım, 2000, 2003, 2006; Karadağ, 2007; Kaya vd., 2012) aile desteğinin öğrencinin başarısını olumlu yönde etkilediği yönündeki bulgularla örtüşmektedir.

Yapılan araştırmadan elde edilen bulguların aşağıdaki öneriler getirilebilir:

- Anne ve babaların çocuklarını daha demokratik bir ortamda yetiştirebilmeleri için eğitim seviyelerini arttıracak her türlü fırsatı değerlendirmeleri gerektiği önerisinde bulunulabilir. Eğitim seviyesinin yükselmesiyle gelir düzeyi daha yüksek mesleklerde yer alan ve daha kaliteli bir yaşam sürebilen anne babaların; hayattan ne beklediğini bilen ve bunun için plan program yapabilen, daha başarılı çocuklar yetiştirebilecekleri söylenebilir.

- Anne ve babaların çocuklarına olan tutumlarında istikrarlı olmaları gerekmektedir. Yaşları ilerleyen ve her geçen gün biraz daha farklılaşan çocuklarına karşı tutum ve davranışları değişen ebeveynlerin, nerde nasıl davranması gerektiğini bilmeyen, tutarsız bireyler yetiştirmeleri kaçınılmazdır. Bunun için ailelerin çocuk gelişimi, ergen gelişimi gibi konularda çeşitli seminerler veya eğitimlere tabi tutularak destek almaları sağlanmalıdır. 
- Düzenlenen eğitim faaliyetleri genellikle annelerin katılımıyla gerçekleşmektedir. Bu tür eğitim organizasyonlarına babaların da katıımını sağlayacak düzenlemeler yapılmalıdır (Babalar için akşam düzenlenen veli toplantıları, babalar ve çocukların katılacağı babalar ve çocukları şenliği vb.).

\section{Kaynakça}

Acıyan, A. A. (2008). Ortaöğretim öğrencilerinin okuma alışkanlıkları ve akademik başarı düzeyi arasındaki ilişki. İstanbul: Yayınlanmamış yüksek lisans tezi, Yeditepe Üniversitesi.

Adıgüzel, E. (2011). 'Öğrencilerin duygusal zekâ ve öğrenme stratejileri ile akademik başarıları arasındaki ilişkiyi belirlemeye yönelik bir alan araştırması. Yayınlanmamış yüksek lisans tezi, Ankara: Gazi Üniversitesi Eğitim Bilimleri Enstitüsü.

Altınkurt, Y. (2008). Öğrenci devamsızlıklarının nedenleri ve devamsızlığın akademik başarıya olan etkisi. Dumlupınar Üniversitesi Sosyal Bilimler Dergisi, Sayı:20.

Arı, A. (2007). Öğrencilerin okul başarılarını etkileyen çeşitli faktörlerin incelenmesi. Milli Eğitim Dergisi, 176, 169-179.

Arısoy, B. (2011). İşbirlikli öğrenme yönteminin ötbb ve tot tekniklerinin 6. sınıf öğrencilerinin matematik dersi "istatistik ve olasılık" konusunda akademik başarı, kalıclık ve sosyal beceri düzeylerine etkisi. Yayınlanmamış yüksek lisans tezi, Adana: Çukurova Üniversitesi Sosyal Bilimler Enstitüsü.

Atkınson, R. L. vd. (2002). Psikolojiye giriş, Ankara.

Aydede, M. N. (2006). Ilköğretim altıncı sınıf fen bilgisi dersinde aktif öğrenme yaklaşımını kullanmanın akademik başarı, tutum ve kalııılık üzerine etkisi. Yayınlanmamış yüksek lisans tezi, Adana: Çukurova Üniversitesi Sosyal Bilimler Enstitüsü.

Burger, J. M. (2006). Kişilik (psikoloji biliminin insan doğasına dair söyledikleri). (Çev: İnan Deniz Erguvan Sarıŏlu), istanbul.

Çelenk, S. (2003). Okul başarısının ön koşulu: okul aile dayanışması. Illköğretim-Online E-Dergi, 2 (2), 28-34, http://www.ilkogretim-online.org.tr adresinden 18 Mart 2012 tarihinde indirilmiştir.

Dinçer, B. (2008). 'Alt ve üst sosyo-ekonomik düzeyde lise ikinci sınıfa devam eden ergenlerin anne baba tutumlarını algılamaları ile arkadaşlık ilişkilerinin incelenmesi', Yayınlanmamış yüksek lisans tezi, Ankara: Ankara Üniversitesi, Sosyal Bilimler Enstitüsü.

Ekşi, A. (1990). Çocuk, genç ve ana babalar, ìstanbul.

Elmacıoğlu, T. (1998). Başarıda aile faktörü, İstanbul.

Gelir, E. (2009). Ana baba tutumları, aile sosyal atomu ve cinsiyete göre ilköğretim altıncı sınıf öğrencilerinin öğrenilmiş çaresizlik ve akademik başarılarının incelenmesi. Yayınlanmamış yüksek lisans tezi, Çukurova Üniversitesi, Adana.

Gökçedağ, S. (2001). Lise öğrencilerinin okul başarısı ve kaygı düzeyi üzerinde anne baba tutumlarının etkilerinin belirlenip karşılaştııılması. Yayınlanmamış yüksek lisans tezi, İzmir: Dokuz Eylül Üniversitesi Sosyal Bilimler Enstitüsü.

Karadağ, ì. (2007). İlköğretim beşinci sınıf öğrencilerinin akademik başarılarının sosyal destek kaynakları açısından incelenmesi. Yayınlanmamış yüksek lisans tezi, Adana: Çukurova Üniversitesi.

Kasatura, í. (1991). Okul başarısından hayat başarısına başarıyı arttıran ya da engelleyen etkenler, İstanbul.

Kaşarcı, İ. (2013). Proje tabanlı öğrenme yaklaşımının öğrencilerin akademik başarı ve tutumlarına etkisi: bir meta-analiz çalışması. Yayınlanmamış yüksek lisans tezi, Eskişehir: Eskişehir Osmangazi Üniversitesi Eğitim Bilimleri Enstitüsü.

Kavcar, B. (2011). Duygusal zekâ ile akademik başarı ve bazı demografik değişkenlerin ilişkileri: bir devlet üniversitesi örneği. Doktora tezi, Ankara: Ankara Üniversitesi Sosyal Bilimler Enstitüsü. 
Kaya, A., Bozaslan, H., Genç, G. (2012). Üniversite öğrencilerinin anne-baba tutumlarının problem çözme becerilerine, sosyal kaygı düzeylerine ve akademik başarılarına etkisi. Dicle Üniversitesi Ziya Gökalp Eğitim Fakültesi Dergisi, 18, 208-225.

Keskin, G.,Sezgin, B. (2009). Bir grup ergende akademik başarı durumuna etki eden etmenlerin belirlenmesi. Fırat Sağlık Hizmetleri Dergisi, 4,10, 3-18.

Locke, J. (1990). Eğitim üzerine düşünceler, İstanbul.

Moralar, A. (2012). Fen eğitiminde probleme dayalı öğrenme yaklaşımının akademik başarı, tutum ve motivasyona etkisi. Yayınlanmamış yüksek lisans tezi, Trakya Üniversitesi Fen Bilimleri Enstitüsü Edirne.

Nimsi, E. (2006). İlköğretim ikinci sınıf öğrencilerinin ana-baba tutumları ile okul başarıları ve sınıf içi etkinlik düzeylerinin karşılaştırılması. Yayınlanmamış yüksek lisans tezi, Uludağ Üniversitesi, Bursa.

Onat, G. (2010). Demokratik ve otoriter olarak algılanan ana-baba tutumlarının lise birinci sınıf öğrencilerinin yılmazlık düzeyine etkilerinin araştırılması. İstanbul: Yayınlanmamış yüksek lisans tezi, Maltepe Üniversitesi.

Özben, Ş. (1995). Lise öğrencilerinin akademik başarısızlıkları ve nedenlerine bakışları. Buca Eğitim Fakültesi Dergisi, 8, 121-133.

Özyurt, S.; Girgin, N. (2000). Gelişim süreçleri insan nasıl öğrenir, Adapazarı.

Razon, N. (1987). Öğrenme olgusu ve okul başarısını etkileyen faktörler. Eğitim ve Bilim Dergisi, Şafak Matbaası, Cilt:11 Sayı: 63, Ankara.

Savaşçı, H. S. (2010). 'Sosyoekonomik değişkenlerin ve okulun eğitim kaynaklarının ilköğretim 7. sınıf öğrencilerinin akademik başarı düzeyleri ile ilişki durumu', Yayınlanmamış yüksek lisans tezi, Mehmet Akif Ersoy Üniversitesi Sosyal Bilimler Enstitüsü, Burdur.

Şendil, G. ve Demir, K. E. (2008). Ebeveyn tutum ölçeği. Türk Psikoloji Yazıları, 11 (21), 15-25.

Toksoy, M. (2009). Yapılandırmacı kurama göre hazırlanan atatürk ilkeleri programının öğrencilerin akademik başarı ve tutumuna etkisi. Yayınlanmamış yüksek lisans tezi. Trabzon: Karadeniz Teknik Üniversitesi Sosyal Bilimler Enstitüsü.

Uyanık B. G. (2007). İlköğretime başlayan çocukların anne babalarının çocuk yetiştirme tutumlarının okul öncesi eğitimden yararlanma düzeylerine göre incelenmesi. Eğitim ve Bilim, , 32, 143, 89-99.

Ünal, E. (2001). Okulun fiziksel ve sosyal yeterliliklerinin akademik ve sosyal başarıya etkisi. Yayınlanmamış yüksek lisans tezi, Niğde: Niğde Üniversitesi Sosyal Bilimler Enstitüsü.

Yavuzer, H. (2011). Ana-baba ve çocuk, İstanbul.

Yıldırım, i. (2000). Akademik başarının yordayıcısı olarak yalnızlık, sınav kaygısı ve sosyal destek. Hacettepe Üniversitesi Eğitim Fakültesi Dergisi, 18, 167 - 176.

Yıldırım, i. ve Ergene, T. (2003). Lise son sınıf öğrencilerinin akademik başarılarının yordayıcısı olarak sınav kaygısı, boyun eğici davranışlar ve sosyal destek. Hacettepe Üniversitesi Eğitim Fakültesi Dergisi, 25, 224234.

Yıldııı, ì. (2006). Akademik başarının yordayıcısı olarak gündelik sıkıntılar ve sosyal destek, Hacettepe Üniversitesi Eğitim Fakültesi Dergisi, 30, 258-267.

Yıldırım, ì. (2010). Anne baba desteği ve başarı- anne babalar çocuklarına nasıl destek olabilirler?, Ankara.

Yılmazer, Y. (2007). Anne-baba tutumları ile ilköğretim ikinci kademe öğrencilerinin okul başarısı ve özerkliklerinin gelişimi arasındaki ilişkinin incelenmesi. Yayınlanmamış yüksek lisans tezi, Ankara: Hacettepe Üniversitesi Sağlık Bilimleri Enstitüsü.

Yücel, C. (2011). Beyin temelli öğrenme yaklaşımına göre fen ve teknoloji öğretiminin akademik başarı ve tutum üzerine etkisi. Yayınlanmamış yüksek lisans tezi. Eskişehir: Eskişehir Osmangazi Üniversitesi Eğitim Bilimleri Enstitüsü. 